\title{
Influence of sintering technology on microstructure and mechanical properties of $\mathrm{ZrB}_{2}-\mathrm{YAG}-\mathrm{Al}_{2} \mathrm{O}_{3}$ ceramics
}

\author{
Jie-Guang Song ${ }^{1 \mathrm{a}}$, Ming-Han $\mathrm{Xu}^{1}$, Shi-Bin $\mathrm{Li}^{1}$, Shi-Zhe $\mathrm{Li}^{1}$, Ting-Ting $\mathrm{Xia}^{1}$, \\ Yao-Qi Li ${ }^{1}$,Ning Wang ${ }^{1}$, Si-Yuan $\mathrm{Yu}^{1}$ and Lin Chen ${ }^{2}$ \\ ${ }^{1}$ Engineering \& Technology Research Center for Materials Surface Remanufacturing of Jiangxi \\ Province, School of Mechanical and Materials Engineering, Jiujiang University, Jiujiang 332005, \\ China \\ ${ }^{2}$ School of Materials and Chemical Engineering, Pingxiang University, Pingxiang 337055, China \\ a songjieguang@163.com
}

Keywords: Ultra-high-temperature ceramics; $\mathrm{ZrB}_{2}$; Sintering technology; Mechanical property.

Abstract. $\mathrm{ZrB}_{2}$, YAG and $\mathrm{Al}_{2} \mathrm{O}_{3}$ are widely applied because of some excellent performances, but $\mathrm{ZrB}_{2}$ is easily oxidized in the high-temperature air. To keep advantages and improve disadvantages of $\mathrm{ZrB}_{2}$, the shell-core structure $\mathrm{A}_{2} \mathrm{O}_{3}-\mathrm{Y}_{2} \mathrm{O}_{3} / \mathrm{ZrB}_{2}$ composite powders are prepared by the co-precipitation methods, the high density $\mathrm{ZrB}_{2}-\mathrm{YAG}-\mathrm{Al}_{2} \mathrm{O}_{3}$ ceramics is prepared by the spark plasma sintering (SPS). The mechanical properties of prepared ceramics under the 20MPa sintering pressure and 4min holding time are shown, which indicates the mechanical properties are increased with increasing sintering temperature, and the increasing ratio of mechanical properties is faster at sintering temperature from $1300^{\circ} \mathrm{C}$ to $1700^{\circ} \mathrm{C}$. When the sintering condition is $1700^{\circ} \mathrm{C}, 20 \mathrm{MPa}$ and 4 minutes, the Young's modulus and the fracture toughness are $421.8 \mathrm{GPa}$ and $12.23 \mathrm{MPam} 1 / 2$, respectively. The reinforced phase $\left(\mathrm{YAG}-\mathrm{Al}_{2} \mathrm{O}_{3}\right)$ is coated on the surface of $\mathrm{ZrB} 2$ crystal, that is to say, the YAG- $\mathrm{Al}_{2} \mathrm{O}_{3}$ is show on the crystal boundary, which is help for the densification and the mechanical properties.

\section{Introduction}

$\mathrm{ZrB}_{2}$ is posed particular interest due to the unique property combination of high refractoriness, high-electrical and high-thermal conductivity, chemical inertness against molten metals or nonbasic slags and good thermal shock resistance [1], which is became candidates for hightemperature applications where corrosion-wear-oxidation resistance is demanded. $\mathrm{ZrB}_{2}$ poses several applications such as Hall-Heroult cell cathodes for electrochemical processing of aluminium, evaporation boats, crucibles for handling molten metals, thermowell tubes for steel refining, thermocouples sleeves for high-temperature uses, nozzles, plasma electrodes, or as dispersoid in metal and ceramic-matrix composites for heaters and igniters. In addition, $\mathrm{ZrB}_{2}$ is a metallic conductor with electrical resistivity comparable with those of their parent metals. This permits to produce complex components at reduced shaping costs. $\mathrm{ZrB}_{2}$, because of its higher costs of production, has found a limited number of applications [2].

Yttrium aluminum garnet (YAG) with a chemical composition of $\mathrm{Y}_{3} \mathrm{Al}_{5} \mathrm{O}_{12}$ is an important advanced structural and functional material. Because of its relatively stable lattice structure and large thermal conductivity, it is used as a host for solid-state laser materials in luminescence systems and in the window material for a variety of lamps. YAG also has great potential application as a high-temperature engineering material because of its good high-temperature strength as well as its superior creep resistance [3-4].

To keep advantages and improve disadvantages of $\mathrm{ZrB}_{2}$, the shell-core structure $\mathrm{A}_{1} \mathrm{O}_{3}-\mathrm{Y}_{2} \mathrm{O}_{3} / \mathrm{ZrB}_{2}$ composite powders were prepared by the co-precipitation methods, the high density $\mathrm{ZrB}_{2}-\mathrm{YAG}-\mathrm{Al}_{2} \mathrm{O}_{3}$ ceramics is prepared by the spark plasma sintering (SPS) and the microstructure and mechanical properties were investigated. 


\section{Materials and experimental}

Analytical grade of aluminum nitrate, yttrium nitrate, ammonia and commercially available $\mathrm{ZrB}_{2}$ powder (99.5\% in purity) were used. $\mathrm{ZrB}_{2}$ particles were coated with $\mathrm{Al}_{2} \mathrm{O}_{3}-\mathrm{Y}_{2} \mathrm{O}_{3}$ composite particles via the co-precipitation method. $\mathrm{ZrB}_{2}-\mathrm{YAG}-\mathrm{Al}_{2} \mathrm{O}_{3}$ ceramics were prepared using coated $\mathrm{Al}_{2} \mathrm{O}_{3}-\mathrm{Y}_{2} \mathrm{O}_{3} / \mathrm{ZrB}_{2}$ shell-core composite particles on the surface of $\mathrm{ZrB}_{2}$ particles with spark plasma sintering (SPS).

$\mathrm{ZrB}_{2}-\mathrm{YAG}-\mathrm{Al}_{2} \mathrm{O}_{3}$ ceramics were prepared with the SPS (Mode: SPS-1050, Japan). Phase analysis was identified by X-ray powder diffraction (XRD) (Model: D/Max-RB, Japan). Microstructure analysis was performed by scanning electron microscopy (SEM) (Model: JSM-5610LV, Japan). Mechanical properties of $\mathrm{ZrB}_{2}-\mathrm{YAG}-\mathrm{Al}_{2} \mathrm{O}_{3}$ ceramics was tested.

\section{Results and discussion}

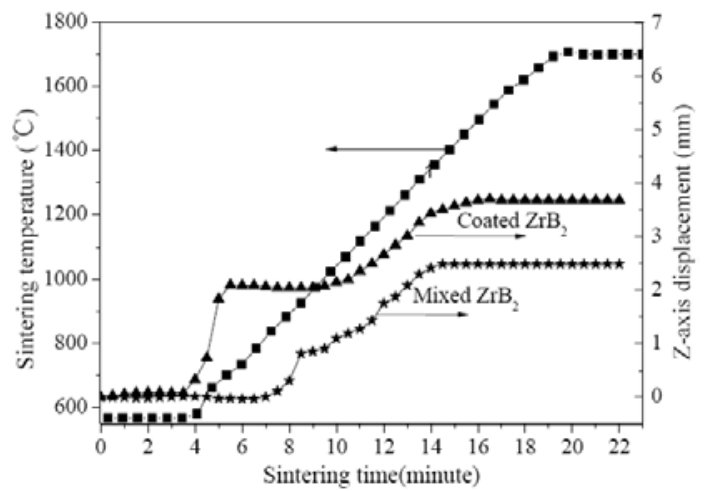

Fig.1 Sintering shrinkage curve of $\mathrm{ZrB}_{2}-\mathrm{YAG}-\mathrm{Al}_{2} \mathrm{O}_{3}$ ceramics

The sintering curves for preparing $80 \mathrm{wt} \% \mathrm{ZrB}_{2}-\mathrm{YAG}-\mathrm{Al}_{2} \mathrm{O}_{3}$ multiphase ceramic materials from different composite raw materials with the spark plasma sintering technique are shown in Fig.1. The Z-axis displacement of spark plasma sintering shows the shrinkage state of a ceramic body during the sintering process, when the value of the $\mathrm{Z}$-axis displacement increases, this indicates the ceramic body is shrinking. The $\mathrm{Z}$-axis displacement shows the shrinkage state of coated $\mathrm{Al}_{2} \mathrm{O}_{3}-\mathrm{Y}_{2} \mathrm{O}_{3}$ powders and mixed YAG powders, respectively. The composite powders with $\mathrm{Al}_{2} \mathrm{O}_{3}-\mathrm{Y}_{2} \mathrm{O}_{3}$ coated show a rapid shrinkage displacement from $700^{\circ} \mathrm{C}$ to $1000^{\circ} \mathrm{C}$, where the second biggish shrinkage displacement also is shown from $1000^{\circ} \mathrm{C}$ to $1600^{\circ} \mathrm{C}$, the Z-axis displacement is not varied basically above $1600^{\circ} \mathrm{C}$. The sintering temperature curve is broken down into four parts, which include the preheating process below $700^{\circ} \mathrm{C}$, the reaction process from $700^{\circ} \mathrm{C}$ to $1000^{\circ} \mathrm{C}$, the sintering process from $1000^{\circ} \mathrm{C}$ to $1600^{\circ} \mathrm{C}$, and the adjustment of the microstructure above $1600^{\circ} \mathrm{C}$. The densification occurs mainly during the reaction process and sintering process, that is to say, the sintering processing is shown from $700^{\circ} \mathrm{C}$ to $1600^{\circ} \mathrm{C}$. YAG is produced from $700^{\circ} \mathrm{C}$ to $1000^{\circ} \mathrm{C}[5-6]$. The reaction temperature is lower than the $1100^{\circ} \mathrm{C}$ for synthesizing YAG powders from $\mathrm{Al}_{2} \mathrm{O}_{3}-\mathrm{Y}_{2} \mathrm{O}_{3}$ composite powders, because $\mathrm{ZrB}_{2}$ particles are changed electrically during the entire sintering process, which produces a plasma among $\mathrm{ZrB}_{2}$ particles to purify the nearby particle surfaces and increase the sintering activity.

However, the Z-axis displacement for powders with YAG- $\mathrm{Al}_{2} \mathrm{O}_{3}$ added shows a lower shrinkage displacement below $1000^{\circ} \mathrm{C}$, a larger shrinkage displacement is shown from $1000^{\circ} \mathrm{C}$ to $1600^{\circ} \mathrm{C}$, the $\mathrm{Z}$-axis displacement is not varied basically above $1700^{\circ} \mathrm{C}$. The $\mathrm{Z}$-axis displacement adding the different powders both show the same shrinkage state from $1000^{\circ} \mathrm{C}$ to $1600^{\circ} \mathrm{C}$, YAG melts above $1000^{\circ} \mathrm{C}$, the temperature is lowered because of the action of the plasma. Because the results of the two routes both show the $\mathrm{Z}$-axis displacement is not varied basically above $1700^{\circ} \mathrm{C}$, a sintering temperature of $1700^{\circ} \mathrm{C}$ is choosen for preparing high density $\mathrm{ZrB}_{2}-\mathrm{YAG}-\mathrm{Al}_{2} \mathrm{O}_{3}$ multiphase ceramics (Fig.2), the microstructure of $\mathrm{ZrB}_{2}-\mathrm{YAG}-\mathrm{Al}_{2} \mathrm{O}_{3}$ multiphase ceramics are shown in Fig.3, which indicates the density of $\mathrm{ZrB}_{2}-\mathrm{YAG}-\mathrm{Al}_{2} \mathrm{O}_{3}$ ceramics with $\mathrm{Al}_{2} \mathrm{O}_{3}-\mathrm{Y}_{2} \mathrm{O}_{3}$ composite powder coated is higer than that of $\mathrm{ZrB}_{2}-\mathrm{YAG}-\mathrm{Al}_{2} \mathrm{O}_{3}$ ceramics with $\mathrm{YAG}-\mathrm{Al}_{2} \mathrm{O}_{3}$ powder mixed (Fig.3-a, b). The reinforced phase of $\mathrm{ZrB}_{2}-\mathrm{YAG}-\mathrm{Al}_{2} \mathrm{O}_{3}$ ceramics with $\mathrm{Al}_{2} \mathrm{O}_{3}-\mathrm{Y}_{2} \mathrm{O}_{3}$ composite powder coated is 
shown on the grain boundary (Fig.3-c), however, the reinforced phase of $\mathrm{ZrB}_{2}-\mathrm{YAG}-\mathrm{Al}_{2} \mathrm{O}_{3}$ ceramics with YAG- $\mathrm{Al}_{2} \mathrm{O}_{3}$ composite powder mixed is shown among the crystal grain (Fig.3-d).

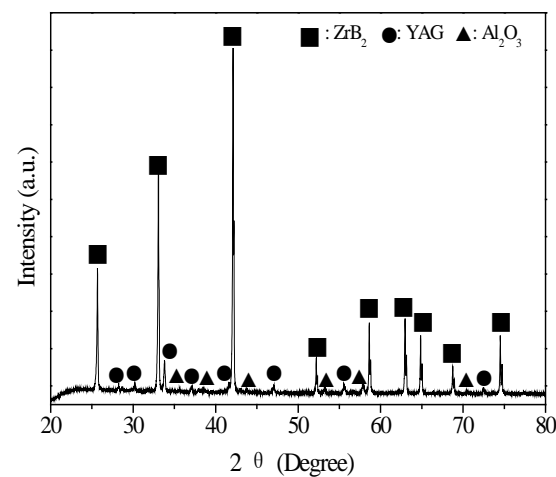

Fig.2 XRD of $\mathrm{ZrB}_{2}-\mathrm{YAG}-\mathrm{Al}_{2} \mathrm{O}_{3}$ ceramics with $\mathrm{Al}_{2} \mathrm{O}_{3}-\mathrm{Y}_{2} \mathrm{O}_{3}$ composite powder coated
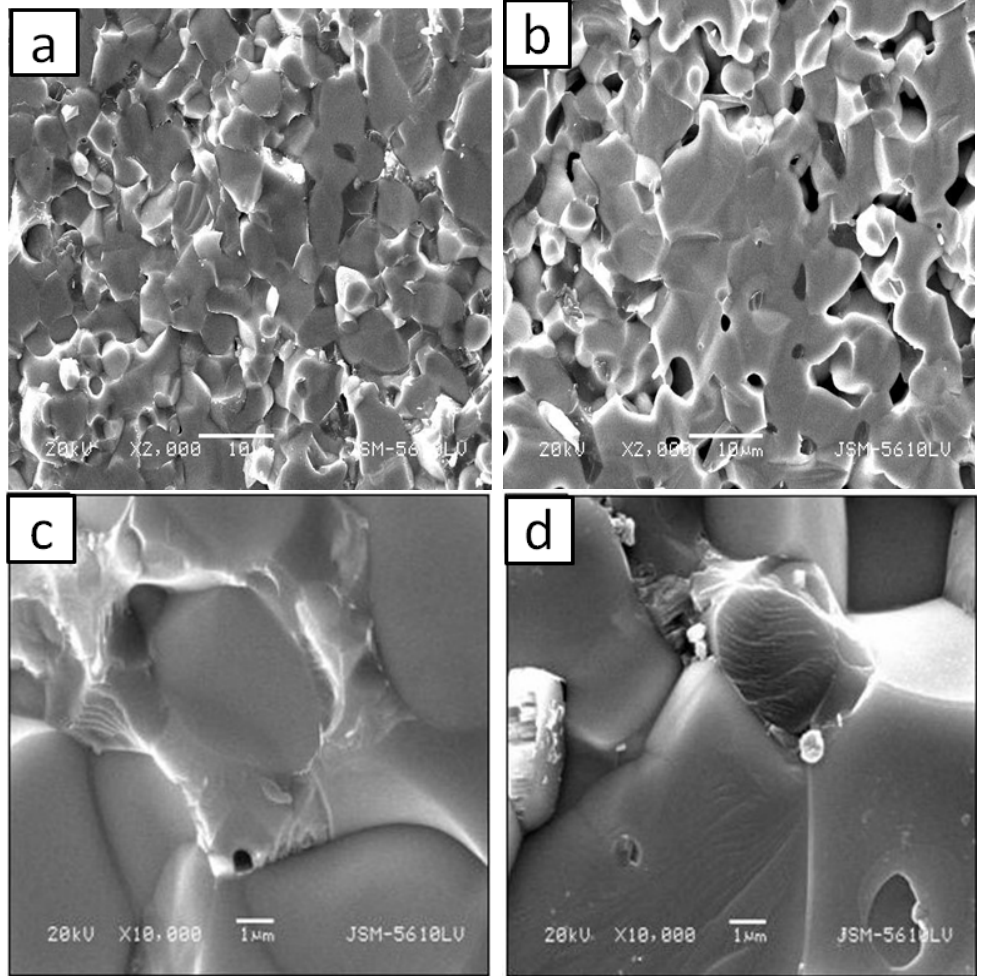

Fig.3 SEM of $\mathrm{ZrB}_{2}-\mathrm{YAG}-\mathrm{Al}_{2} \mathrm{O}_{3}$ ceramics (a, c-Coated powders, b, d-Mixed powders)

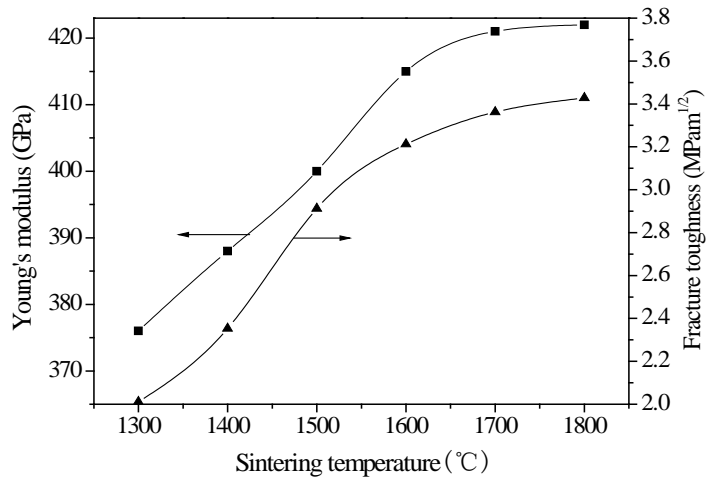

Fig.4 Effect of sintering temperature on Young's modulus and fracture toughness of ceramics

The mechanical properties of prepared ceramics under the 20MPa sintering pressure and $4 \mathrm{~min}$ holding time are shown in Fig.4 and Fig.5, which indicates the mechanical properties are increased with an increasing sintering temperature, and the increasing ratio of mechanical properties is faster at sintering temperature from $1300^{\circ} \mathrm{C}$ to $1700^{\circ} \mathrm{C}$. Because the main desifacation process is produced through the sintering temperature range, the density of ceramics is increased mainly, the Young's modulus and the fracture toughness are $421.8 \mathrm{GPa}$ and $12.23 \mathrm{MPam} 1 / 2$, respectively. When the 
sintering temperature is overed $1700^{\circ} \mathrm{C}$, the Young's modulus and the fracture toughness are increased less, the sintering temerature is decised at $1700^{\circ} \mathrm{C}$.

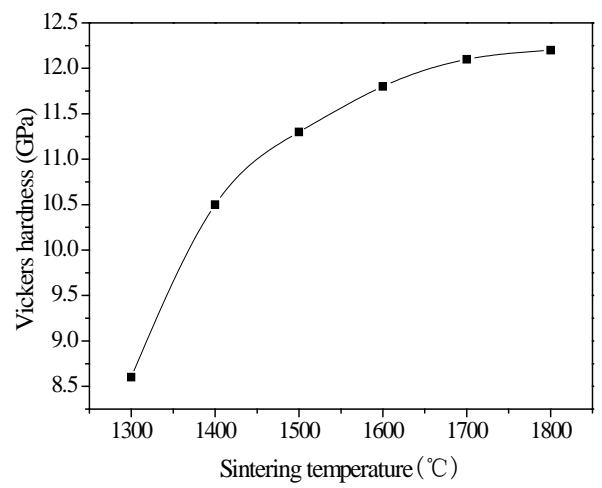

Fig.5 Effect of sintering temperature on hardness of ceramics

\section{Conclusion}

Through the all results and discussions, the conclusions are the $80 \mathrm{wt} \% \mathrm{ZrB}_{2}-\mathrm{YAG}-\mathrm{Al}_{2} \mathrm{O}_{3}$ multiphase ceramic materials posing different composite raw materials with the spark plasma sintering technique were successfully prepared. The mechanical properties of prepared ceramics under the 20MPa sintering pressure and $4 \mathrm{~min}$ holding time are shown, which indicates the mechanical properties are increased with increasing sintering temperature, and the increasing ratio of mechanical properties is faster at sintering temperature from $1300^{\circ} \mathrm{C}$ to $1700^{\circ} \mathrm{C}$. When the sintering conditons is $1700^{\circ} \mathrm{C}, 20 \mathrm{MPa}$ and 4 minutes, the Young's modulus and the fracture toughness are 421.8 GPa and 12.23 $\mathrm{MPam}^{1 / 2}$, respectively. The reinforced phase (YAG- $\mathrm{Al}_{2} \mathrm{O}_{3}$ ) is coated on the surface of $\mathrm{ZrB}_{2}$ crystal, that is to say, the YAG-Al ${ }_{2} \mathrm{O}_{3}$ is show on the crystal boundary, which is help for the densification and the mechanical properties.

\section{Acknowledgements}

The authors are thankful for the financial support provide by The Natural Science Foundation of Jiangxi Province, China (20114BAB216023), the Key Subjects Construction Program for the Materials Processing Engineering of Jiangxi Province during the 12th Five-Year Plan Period, the Science and Technology Found of Educational Department of Jiangxi Province, China (KJLD12096) and the Science and Technology Foundation of Jiujiang University, China (2014KJZD004).

\section{References}

[1] S.M. Zhang, S. Wang, Y.L. Zhu, Fabrication of $\mathrm{ZrB}_{2}-\mathrm{ZrC}$-based composites by reactive melt infiltration at relative low temperature, Scripta Mater. 65 (2011) 139-142.

[2] J. Watts, G. Hilmas, W.G. Fahrenholtz, Measurement of thermal residual stresses in $\mathrm{ZrB}_{2}-\mathrm{SiC}$ composites, J. Eur. Ceram. Soc. 31 (2011) 1811-1820.

[3] Y.H. Huang, D.L. Jiang, J.X. Zhang, Sintering kinetics of YAG ceramics, J. Rare Earth 32(2014) 416-422.

[4] R. Marder, C. Estournes, G. Chevallier, Spark and plasma in spark plasma sintering of rigid ceramic nanoparticles:A model system of YAG, J. Eur. Ceram. Soc. 35(2015) 211-218.

[5] R.R. Wang, Y.C. Wang, Z.Y. Fu, Phase evolution of YAG powders obtained by gel combustion combined with field-assisted rapid synthesis technique, Ceram. Int. 41(2015) 7289-7295.

[6] S.A. Kumar, J. Senthilselvan, Co-precipitation synthesis and spectroscopic studies of YAG and Yb:YAG nanopowder for opto-electronic applications, Trans. Indian Inst. Metal. 68 (2015) 153-159. 